\title{
KRĘĆ SIĘ, KRĘĆ WRZECIONO. O TKACTWIE I JEGO SYMBOLICE W PERSPEKTYWIE GENDEROWEJ
}

\author{
Marta Rudnicka, m.rudnicka92@gmail.com \\ Uniwersytet im. Adama Mickiewicza \\ Wieniawskiego 1, 61-712 Poznań
}

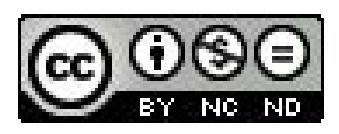

\section{STRESZCZENIE}

Celem niniejszego artykułu jest analiza przypadku tkactwa z regionu łowickiego pod względem symbolicznym, społecznym oraz kulturowym. W tym celu odwołuję się do szerokiego wachlarza przykładów, odnosząc się do historii, symboliki oraz zmieniającej się roli społecznej tkactwa. Jednym z moich priorytetów jest zarysowanie genderowo ukonstytuowanego podziału ról społecznych podczas obróbki lnu, przędzenia i tkania. Przywołuję zatem ukonstytuowane na gruncie humanistyki podziały natura-kultura, domowe-zewnętrzne, a także korzystam z teoriii marksistowskich oraz strukturalistycznych. Jednocześnie nie prowadzę silnie zarysowanej polemiki z żadną z wymienionych teorii, zgodnie z założeniem opisania zjawiska, jakim jest tkactwo w Łowiczu, a nie krytyki naukowej.

Słowa kluczowe: tkactwo, gender, symbolika tkactwa, teorie feministyczne, kulturowy podział ról społecznych

Spin on, spin on. Weaving and its symbolism in the perspective of gender studies

\section{Abstract}

This article aims to examine the case of gender roles intertwined with the tradition of spinning and weaving within the community of Łowicz region, Poland. My interest in this particular case was aroused during fieldwork I conducted there covering the topic of local traditional craft. In my article I pursue the aim by invoking various examples both from history, mythology and scientific theories following the origin and development of spinning and weaving Special attention is paid to feminist, gender, marxist and stucturalist theories with a view of a multidimensional coherent and plausible explanation. In the end I resort to these for an ultimate evaluation of Łowicz's weaving tradition.

Key words: weaving, spinning, gender roles, weaving symbolism, feminist theories

\section{WPROWADZENIE}

Szur. Szur. Łups.

Oi to tak robi się, widzi?

Łups. Krosna aż drżą w posadach. Są wielkie, ściśle wypełniają zakurzoną przestrzeń małego garażu. Pani Luba ${ }^{1}$, okutana w sweter, chustkę i grube skarpety, z zapałem przeplata wątek w przesmyku² tworzącym się między szorstkimi nitkami osnowy. Łups. Berdo przyciska wątek, lniane nici zmieniają się miejscami karnie jak żołnierze pod dyktando pani Lubej. - Czemu pani nadal to robi? - pytam, patrząc, jak sprawnie czółenko ślizga się od prawej do lewej. Pani Luba uśmiecha się. Tka od zawsze, tka i teraz, póki sił, mimo lat z okładem siedemdziesięciu.

Pierwszy raz zetknęłam się z tkactwem na Podlasiu, podczas antropologicznych badań terenowych przeprowadzonych w kwietniu 2013 r., we wsi Dubicze Cerkiewne. Choć były to jedynie dwa przypadki, w tym pani Lubej, to wystarczyło bym uważniej zaczęła się przyglądać tkackiej tradycji. Dubickie badania skupione były jednak przede wszystkim na krajobrazie kulturowym - tradycji i teraźniejszości, lokalności i regionalności realizujących się w codziennych sposobach myślenia i działania. Tkactwo było tu więc jednym z elementów tożsamości lokalnej i regionalnej (wytwórstwo szmacianych dywaników). Funkcjonowało na zasadzie ginącego zawodu, uprawianego miejscami jako żywa tradycja, którą próbuje się wykorzystywać w celach marketingowo-turystycznych³. To dzięki kolejnym badaniom, tym

1 Opis pochodzi z badań terenowych przeprowadzonych w kwietniu 2013 roku w podlaskiej miejscowości Dubicze Cerkiewne. Informatorka o kodzie

2 M. Żmijewska, Ginace rzemiosta = Disappearing handicraft, 2011.

3 W. Kowalczuk, Propozycja dla koneserów sztuki ludowej, http://www.wrotapodlasia.pl/pl/kultura/sztuka_ludowa/ 16.04.2014. 
razem nad strojem łowickim we wrześniu 2013 r., tkactwo zyskało w moich oczach inny wymiar, który wydał mi się na tyle pasjonujący by poświęcić mu niniejszy artykuł.

\section{TKACTWO A GENDER}

Spora część kwestionariusza, według którego przeprowadzałam wywiady, dotyczyła sposobów sporządzania tkanin. Co wydało mi się znamienne, każdy poszczególny etap obróbki lnu, począwszy od siania na tkaniu skończywszy, przypisywany był przez rozmówczynie konkretnej płci. Zaintrygowana, rozpoczęłam poszukiwania nad symboliką i społeczną percepcją tkactwa, a w miarę poszukiwań wspomniany dychotomiczny podział stawał się coraz bardziej widoczny. Przejawiał się zarówno w sferze symbolicznej, mitycznej jak i historycznej oraz społecznej. Pączkował w literaturę piękna, a stąd na feministyczne literaturoznawstwo, które wyjątkowo mocno eksploatuje ten, nomen omen, wątek. Przykładem niech tutaj będą teksty: Kazimiery Szczuki Przadki tkaczki i pająki, gdzie między innymi autorka interpretuje conocne spruwanie tkaniny przez Penelopę; czy inny - Nancy K. Miller Arachnologie: kobieta, tekst $i$ krytyka. Na podstawie greckiego mitu o Arachne, autorka wysnuwa teorię „,arachnologii” jako metaforycznego tworzenia tekstu. Obie pisarki podejmują też inną kwestię, którą N. K. Miller nazywa „figuracją kobiecego stosunku wytwórczego do panującej kultury"5, czyli tkactwa w ujęciu genderowym.

Temat gender stał się ostatnio czymś w rodzaju uniwersalnej, samowybuchającej petardy, którą wystarczy wrzucić w pozornie spokojny tłum, by ten w okamgnieniu zajął się ogniem sprzeczek, wymianą coraz bardziej wyświechtanych argumentów i coraz mniej zawoalowanych obelg. Nie chcę wchodzić na ten grząski grunt społeczno-politycznego sporu o słuszność bądź niesłuszność teorii gender. Nie będę również przytaczała argumentów, które być może pasowałyby do mojej tezy. W moim artykule gender będzie mnie interesowało wyłącznie z punktu widzenia nauki, którą mam nadzieję uprawiać - antropologii kulturowej. Na gruncie antropologii to pojęcie oznacza: badanie płci kulturowej - sposobów jej kształtowania i praktykowania oraz relacji społecznych wynikających z ustalonych na jej podstawie, to jest płci, ról' ${ }^{6}$.

Teoria gender posłuży mi do próby zanalizowania zjawiska społecznego, jakim jest tkactwo (zarówno w sferze praktycznej, rzemieślniczej, jak i symbolicznej). Odniosę się do trzech podstawowych dychotomii, obszernie przytoczonych i skrytykowanych w artykule O ujednolicona analize płci kulturowej i pokrewieństwa autorstwa S. N. Yanagisako i J. C. Collier. Spróbuję w ten sposób wyjaśnić przyczynę podziału ról społecznych, który zaobserwowałam w Łowiczu.

TKACTWO JAKO RZEMIOSEO A MARKSISTOWSKIE SPOSOBY PRODUKCJI I REPRODUKCJI

Tkactwo jest jednym z najstarszych złożonych metod wytwórczych stworzonych przez człowieka. Jak pisze Tadeusz Wróblewski, obok dość nieaktualnych z dzisiejszego punktu widzenia dyfuzjonistycznych rozważań, ślady warsztatów tkackich można znaleźć już w pozostałościach kultury mezopotamskiej’, datowane na ok. VI tys. lat przed naszą erą. Wróblewski postuluje symultaniczność powstania tego rzemiosła oraz wykształcenia się tak zwanych „kultur wyższych”, czyli, w rozumieniu autora, powstałych ze scalenia się elementów kilku kultur neolitycznych ${ }^{8}$ w jeden organizm społeczny oraz przeprowadzenia rewolucji technologicznej. Jednym z jej efektów było, jak mniemam, wynalezienie krosien.

Podobnego zdania jest także Maguellone Toussaint-Sawat. W swojej książce Historia stroju wskazuje, tak jak T. Wróblewski, na znaleziska archeologiczne z terenów Bliskiego Wschodu, a dokładnie z wyżyny anatolijskiej. Odkryto tam szczątki wełnianego sukna sprzed 9 tys. lat, a więc około VII w. przed naszą erą. Mniej więcej w tym okresie przestają się również pokazywać narzędzia do wyprawiania skór. Autorka ostrożnie sugeruje, że może jest to znak zmian w rodzaju ubioru, jakie ówczesny człowiek wybierał, by odziewać swoje ciało?. Podobne przejście od skór do materiałów tkanych zaobserwować można również na terenie kontynentalnej Europy - w Szwecji, na terenie szwajcarskich palafitów, przy czym odnaleźć tam można odpowiednio - pozostałości tkanek zwierzęcych i roślinnych ${ }^{10}$.

Skupię się na tych ostatnich; konkretnie na lnie, który łączy tkaczy starożytnych i współczesnych.. Ograniczę się również do obszaru Europy, północnej Afryki i Bliskiego Wschodu; lniane tkactwo ma tam nader długą tradycję. Analizę

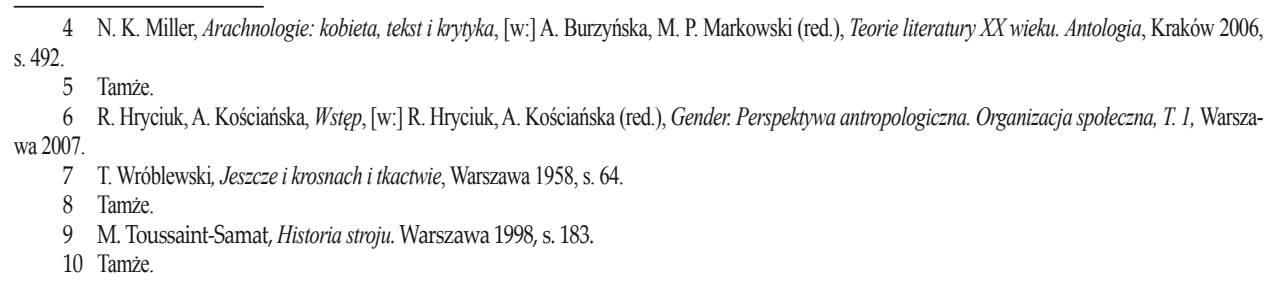


rzemiosła lnianego należy rozpoczać od nakreślenia jego obrazu w starożytnym imperium lnu, czyli Egipcie.

Len tam ceniony był ponad miare, symbolizował czystość (w płócienną biel odziewali się kapłani). Tkaniny wykonywano przy pomocy prymitywnych poziomych krosien, na których na dwa drążki wsparte na kołkach naciagano osnowę. Rysunki takich krosien można znaleźć na ścianach grobowców i papirusach, a z nich odczytać wiele na temat tego, jak wyglądało egipskie rzemiosło ${ }^{11}$. Wynika z nich, że: zbiorem, moczeniem i młóceniem lnu zajmowali się mężczyźni ${ }^{12}$. Różne są natomiast przekazy co do tego, kto zajmował się przędzeniem: być może robili to przedstawicie obu płci. Wspomina o tym Herodot, przekazując skądinąd ciekawą informację na temat organizacji społecznej i realizowania się ról naznaczonych płciowo: „Mają też Egipcjanie zwyczaje i obyczaje prawie pod każdym względem przeciwne aniżeli wszystkie inne ludy. Kobiety u nich przebywają na rynku i handluja, a mężowie siedzą w domu i przędą ${ }^{\prime \prime 13}$. Kobiety z pewnością tkały len na krosnach.

Umiejętność uprawy i obróbki lnu wynieśli z Egiptu Hebrajczycy, idący pod wodzą Mojżesza do Ziemi Obiecanej. Stary Testament wielokrotnie wspomina symboliczną rolę lnu i lnianych szat, które miały być tkane „staranną ręką niewiasty dzielnej, której wartość przewyższa perly ${ }^{\prime \prime 14}$. Jezusową tunikę miała w ten sposób utkać Maria. Nie wiemy, jak tutaj rozkładał się podział obowiązków, ale można przypuszczać, że podobnie jak w Egipcie. Nie wiadomo mi również nic na temat quasi-przemysłowego wytwórstwa tkaniny lnianej. Zważywszy jednak na historię ludu izraelskiego, znajdującego się od VIII w. p.n.e. pod ciagłym panowaniem obcych państw, tkactwem zajmowano się raczej wyłącznie na własny użytek.. Świadczą o tym znaleziska archeologiczne - liczne drewniane krosna ${ }^{15}$. Najprawdopodobniej przędzeniem i tkaniem zajmowały się kobiety.

Świat hellenistyczny wraz zjego potęgą militarną stwarzał zapotrzebowanie na żagle, liny, prostą odzież dla żołnierzy i niewolników, ale także bieliznę, pościel, obrusy, narzuty i zasłony dla pozostałych mieszkańców Cesarstwa ${ }^{16}$. Len był tani i popularny; stąd powstanie licznych zakładów tkackich. Te zakładane w wielkiej ilości na podbijanych ziemiach, prowadzone były przez mężzzyzn, natomiast zatrudniano w nich kobiety. W samym Rzymie być może zajmowali się tym również mężczyźni. W przestrzeni domowej przędzenie i tkanie należało natomiast wyłącznie do sfery zajęć kobiecych, a w każdym domu znajdowała się pracownia tkacka zwana z grecka gynacium ${ }^{17}$.

Uprawa, przetwórstwo i tkactwo lniane nie upadło wraz z cesarstwem rzymskim, ale zostało przejęte przez nastepujące po nim germańskie państewka. Spore ośrodki quasi-przemysłowe wytworzyły się na terenie dzisiejszej Belgii i Wielkiej Brytanii18 ${ }^{18}$ Nazywani z celtycka Bel'ch czyli len (mężczyźni?), skupiali wiedzę o tkactwie w klasztorach, na przykład w założonej przez Karola Wielkiego Brugii. Na południu Półwyspu Apenińskiego, zajętym przez Saracenów do końca wypraw krzyżowych, tkactwem trudniło się wielu Żydów ${ }^{19}$ (mężczyzni?).

Kolejne dziesięciolecia dowodzą zmaskulinizowania coraz żywiej (aż do pojawienia się bawełny) rozwijającego się przemysłu tkackiego. Mężczyźni przewodzili w pomysłach unowocześniania przędzalni, technik splotu i obróbki materiału, by był jak najcieńszy i najdelikatniejszy. Przykładowo: batyst cambricu, kupowany namiętnie przez angielską gentry, mimo obwarowania importu towarów z Francji wieloma zakazami. Jego twórcami byli mężczyźni ${ }^{20}$.

Przypadek dwojakiego lnianego rzemieślnictwa (podzielonego na tę przemysłowo-zewnętrzną część i na tę chałupniczo-domowa), można, jak mi się wydaje, zanalizować pod kątem marksistowskich stosunków produkcji i reprodukcji (w wersii oryginalnej), wzbogaconych o perspektywę feministyczną. Marksistowskie teorie kontroli siły roboczej i jej reprodukcji często sprowadzały rolę kobiet do roli „,środków reprodukcji”21 ${ }^{\prime \prime}$ wskazując zarówno ich zdolność do prokreacji, jak i ich rolę $\mathrm{w}$ inkulturacji dzieci poprzez wychowanie, naturalnie przypisane roli kobiecej. Tę interpretację podejmuje Claude Meillassoux, porównując społeczeństwa przedkapitalistyczne, rolnicze i kapitalistyczne ${ }^{22}$. W tych os-

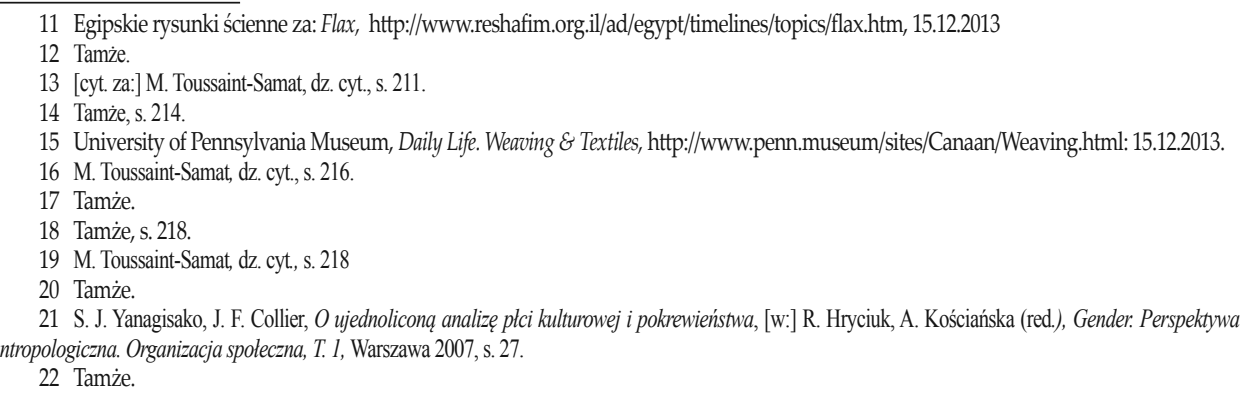


tatnich, mimo rozwoju, nadal najlepszą formą kontroli środków produkcji jest kontrola środków reprodukcji, czyli kobiet. To one „ulegają reprodukcji” (siła robocza) i one „reprodukują" (system społeczny). Feministyczna krytyka skupiła się właśnie na tym wykluczeniu kobiet ze sfery środków produkcji i sprowadzeniu ich do roli wyłącznie reproduktorek.

Ta swego rodzaju „naturalizacja” kobiet oraz kontrola ich działań reprodukcyjnych z jednej strony, a społeczne ograniczenia kobiecej działalności produkcyjnejej3 $\mathrm{z}$ drugiej, nie sa, jak myślę, tożsame wyłącznie dla społeczeństw kapitalistycznych pierwszej połowy XX w. Równie dobrze ich wzór można przyłożyć do społeczności rolniczych w wymiarze produkcji tkackiej.. Gender czyli kulturowo uwarunkowane różnice między płciami i ich wzajemny stosunek, są tu bardzo jaskrawo widoczne. Rola mężczyzn w przemyśle tkackim wzrasta wraz z rozwojem tej gałęzi na rynku narodowym, a następnie międzynarodowym. Tym samym, rola kobiet z jedynych wytwórczyń materiału służącego do odziewania swego ciała, a więc roli niezwykle istotnej, została sprowadzona do chałupniczego, mówiąc dzisiejszymi słowami, hobbystycznego wytwarzania przędzy i tkaniny.

Kiedy mężczyźni przejęli sposoby i środki produkcji, zaczęli gromadzić kapitał i w efekcie zarządzać zarówno nim, jak i wspomnianymi środkami (pieniędzmi, kontaktami handlowymi, fabrykami). Kobiety natomiast to, w tym ujęciu, reproduktorki systemu społecznego, nosicielki określonych relacji społecznych (tu: kreowanych w procesie wytwarzania materiału), a więc także genderowych. Tworzone podczas tych relacji obrazy „"kobiet” i „mężczyzn"24 są powielane, a poprzez działanie zgodnie z przypisanymi im rolami - konstytuują społeczne różnice. To swego rodzaju błędne koło. Te różnice to, w tym przypadku: nierówności w dostępie do środków produkcji i kapitału, a także wytworów produkcji. To także różnice w prestiżu społecznym, który uwidacznia się w rodzaju podejmowanych działań $\mathrm{i}$ ich odbiorze. W tym przypadku to płeć kulturowa, a nie biologiczna, gra główną rolę. Jeżeli chodzi o tkactwo, rzecz miała się najzupełniej podobnie.

TKACTWO W WYMIARZE SYMBOLICZNYM. DYCHOTOMIE NATURA-KULTURA, DOMOWEPUBLICZNE

Symbolika tkactwa jest rozbudowana; warto się zastanowić, dlaczego. Czy dlatego, że jest to czynność wielowymiarowa, angażujące wiele rodzajów wiedzy, naturęi technikę? Czy może sam proces tkania jest tak inspirujący? Autorka Historii stroju w dziale o symbolice tkania i przędzenia, mówi o tym, że w wielu wierzeniach przeplatanie się nici osnowy i wątku jest niemal oczywistą alegorią ludzkiego życia ${ }^{25}$. Osnowa na kształt zewnętrznej, wobec jednostki, historii (przemijającego czasu) kreuje przebieg ludzkiego życia (wątku) a każda zmiana ustawienia osnowy to wydarzenie w naszym życiu. Poczynając od tego podstawowego założenia wychodzi się dalej, do mitologicznych postaci jak Mojry czy Parki, bóstw prządek jak pisze o nich K. Szczuka: „dbałe o pierwszą i ostatnią szatę człowieka: pieluszkę i pogrzebowy całun”26.

Niemal każda mitologia świata ma w swoim panteonie takie bóstwa, do obowiązków których należy przekazywanie praktyk tkackich, opiekowanie się nimi lub, tak jak Mojry - symbolicznego sprawowania pieczy nad ciagłością ludzkiego życia. Należy zauważyć, że były to wyłącznie bóstwa rodzaju żeńskiego. Poczynając od bóstw zaangażowanych w tę najstarszą symboliczną rolę - czuwanie nad ludzkim losem: greckie Mojry, rzymskie Parki a także obecne w mitologii pótnocnych ludów trzy inne postacie: Urðr, Verðandi i Skuld ${ }^{27}$ (przeszłość, teraźniejszość i przyszłość). Podobne motywy pojawiają się w mitologiach anglosaskiej, francuskiej, niemieckiej i orientalnych ${ }^{28}$. Boginie-prządki z Francji i Niemiec sa, jak pisze M. ToussaintSarmat, czczone w van gennepowskim okresie przejścia od starego roku do nowego. Pojedyncze boginie, odpowiedzialne odpowiednio za przędzenie lub tkanie, albo za obie czynności, pojawiają się jeszcze częściej. Wspomnę tu również Atenę, Habetrot, Neit, Paivatar, Ruana Nieda Sunnę czy Wakahirume; ich atrybutami były kądziele, kołowrotki lub pająki²

Wspomniany wyżej dualizm tkacki - wątek-osnowa, interpretowany jest na wiele sposobów: to przemiana dni i nocy, rytm życia, jasność i mrok, kobieta i mężczyzna, jin i jang. To, jak pisze autorka Historii stroju: „przemiana i dopełnianie się,

\footnotetext{
23 Tamże, s. 24.

24 Mam tu na myśli rozdźwięk między biologicznym a kulturowym ujęciem płci, gdzie „męskie” $\mathrm{i}$ „żeńskie” to przymioty wytwarzane w procesie swoistej inkulturacji, zob. Hryciuk R., Kościańska A., Wstęp, [w:] R. Hryciuk, A. Kościańska (red.), Gender. Perspektywa antropologiczna. Organizacja społeczna, T. 1, Warszawa 2007.

25 M. Toussaint-Samat, dz. cyt., s. 287

26 K. Szczuka, Przadki, tkaczki i pajaki, [w:] G. Borkowska, L. Sikorska (red.), Krytyka feministyczna: siostra teorii i historii literatury, Warszawa 2000.

27 M. Toussaint-Samat, dz. cyt., s. 288

28 Goddeses Who Weave and Spin, http://www.crystalinks.com/weaving_goddess.html, 15.12.2013.

29 On the Mythology of Weaving, http://tres-hermanas-weaver.blogspot.com/2009/09/on-mythology-of-weaving.html, 15.12.2013.
}

OGRody NAUK I SZTUK NR 2014 (4) 
rytm i równowaga świata"30. Wymienione binarne opozycje są w jakiś sposób stwórcze: dnie i noce tworzą przemijający czas, kobieta i mężczyzna dają życie kolejnym pokoleniom - tak jak wątek i osnowa dają tkaninę. Cytowany we wspomnianej książce Peter Huges uważa, że tkanina jest pierwszym stworzonym przez człowieka systemem binarnym, zerojedynkowym, w którym wątek wolny, przechodzący nad nicią osnowy, odpowiada jedynce, a przechodzący pod osnową -zeru. Tak programowany układ daje w efekcie tkaninę. Huges porównujeją do pamięci - „opartej na grze układu nici" ${ }^{\prime 31}$. Pamięć można też utożsamiać z życiem jako takim - czyli również tkaniną.

Kądziel, kojarzono z typowo damskim zajęciem (odziany w damskie suknie Herkules, przędący w stóp Omfalii jest symbolem odarcia z męskości, moralnej kastraciji ${ }^{22}$ ), wrzeciono natomiast jest według Marie-Luise von Franz: „poprzez swój kształt (...) przedmiotem o charakterze fallicznym ${ }^{\prime \prime 33}$. Obecny w wielu baśniach motyw wrzeciona, jak choćby w Spiacej Królewnie czy grimmowskim Wrzecionie, czótenku i igle, oznacza kobiecość, zwłaszcza tę odkrytą w zderzeniu z męskością lub tę pokorna, związaną mocno z przynależną jej sferą. Wrzeciono to też narzędzie wiedźm i czarownic, które mszczą się za odebraną z wiekiem kobiecośc ${ }^{34}$.

Nakreślony przeze mnie pokrótce symbolizm tkacki, chciałabym zanalizować pod kątem innych podstawowych dychotomii, tak samo mocno osadzonych, jak często krytykowanych w ramach ideologii gender. Mówię tutaj o binarnej opozycji: natura - kultura oraz domowe - publiczne, które w istocie nachodzą na siebie i wzajemnie uzupełniają. Te dwie opozycje odpowiadają oczywiście płciom - tym biologicznym i tym ukonstytuowanym kulturowo. Opierają się na biologii, w której zróżnicowanie płciowe jest uważane za niejako „dane z natury” a więc "prawdziwsze”, „czysto ludzkie”, przedspołeczne i przedkulturowe. W antropologii kulturowej istnieje pogląd (dość ewolucjonistyczny, z którym nie do końca się zgadzam), że kultura jest $\mathrm{w}$ prostej linii efektem doboru naturalnego $0^{35}$, a więc, mówiąc prosto: jest osadzona i ukształtowana przez naturę. Jest jej nadbudowa, stworzoną na zasadzie opozycji tego, co Zygmunt Bauman nazywa chaosem - przyrody ${ }^{36}$.

Claude Levi-Strauss rozpoznawał, że pojmowanie natury i kultury zależne jest wyłącznie od jednostki i tej kultury, w której się obraca ${ }^{37}$. Tym niemniej wierzył w kształtującą moc tej opozycji. Wierzą w nią również autorki artykułu O ujednolicona analize płci kulturowej... , które piszą: „,oczywiście zupełnie nie wiadomo, co znaczyłaby płeć kulturowa czy pokrewieństwo, gdyby były całkowicie pozbawione związków z płcią biologicznąi rozmnażaniem płciowym. Nie mamy innego wyjścia, jak tylko badać innych za pomocą naszych własnych pojęc' ${ }^{\prime \prime 38}$. Więc również tutaj nie uniknę uwikłania w tę nomenklaturę.

W symbolice tkackich odwołań do kobiecości i męskości, a także kulturowo ukształtowanych „kobiecości” i „męskości" objawiających się w różnoraki sporób, jest bardzo wiele. Zaczynając oczywiście od płci bogin opiekuńczych i tych, które poprzez czynności przaśnickie czuwały nad ludzkim życiem - były to kobiety. Zakładając, że wyobrażenia religijne bóstw były odbiciem wyobrażeń - konstruktów społecznych danych społeczeństw, można zakładać, że tą sferą działalności i wytwórczości również zajmowały się kobiety. Źródła historyczne podaja, że tak właśnie było, aczkolwiek trzeba tutaj poczynić pewne zastrzeżenia: Po pierwsze: czysto kobiecym zajęciem było wyłącznie przędzenie (tylko jedna wzmianka wspomina o przędzących mężczyznach - Egipcjanach), czynność nadal zastrzeżona dla przestrzeni domowej (tkactwo jako przemysł wyszło poza ramy domostw dość szybko, zyskując zupełnie inny status - nie-symboliczny). Tak wiec przędzenie - kobiecość - sfera domowa - natura. I opozycyjnie: tkanie - męskość - sfera publiczna - kultura.

Kądziel bliższa była naturze poprzez kształt i kontakt z czystym, nieprzerobionym surowcem, któremu dopiero zręczne palce przaśniczek nadawały kształt. Krosna to już wynalazek, używając neomenklatury T. Wróblewskiego, kultur wyższych, a więc kultury jako takiej. Tym bardziej zinstytucjonalizowany przemysł, na czele którego stali mężczyźni, dominujący przez lata na arenie pozadomowej, bezdyskusyjnie przynależny był do tej sfery. Nie jestem pewna, na ile możemy tu mówić o postulowanej przez przytoczonych wcześniej naukowców fundamentalnej potrzebie postępowanie według prawideł natury, czyli płciowo uwarunkowanej predestynacji do takiego, a nie innego podziału ról i obowiązków. Czy jest

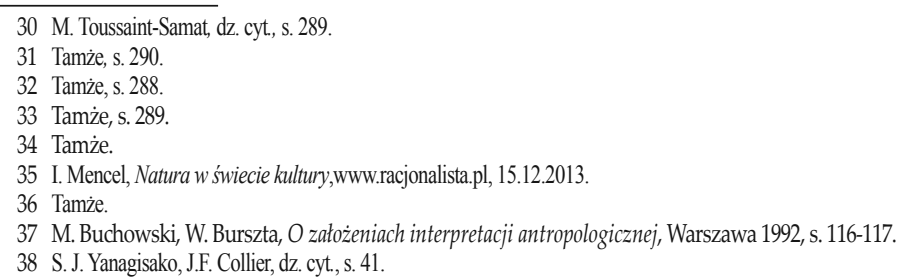


to, jak piszą S. Yanagisako i J. Collier, „przetworzenie i rozwinięcie jednego i tego samego faktu przyrodniczego ”39, czy można mówić o unizersalnej asymetrii pomiędzy płciami - biologicznymi, a przez to - kulturowymi?

Faktem jest, że panujący przez wieki w Europie patriarchat mógł mieć wpływ na takie ukształtowanie się kobiecych i męskich ról, na dominację męską w sferze przemysłowej, a pozostawienie sfery domowej pod jurysdykcją kobiet. Nie uważam za słuszne przypisywania tym praktykom jakichkolwiek wartości, mniejszych lub większych, w zależności od ich przynależności do sfery kultury lub natury. Być może środowiska feministycznie nie zgodziłyby się z takim tokiem myślenia. . Antropologiczne stosunki społeczne starają się jednak nie skupiać na tej, niejako hierarchicznej, stronie relacji społecznych. Ija też jestem zwolenniczką takiego podejścia.

\section{GENDER w ŁOWICZU - WTÓRNA ANALIZA}

Zbierając to, co wcześniej starałam się nakreślić i w konkretny sposób zanalizować, chciałabym powrócić do mikro-praktyk tkactwa lnianego w Łowiczu. Moim celem w tym artykule było, poprzez nakreślenie szerokiego tła dla tego pojedynczego przypadku, wyjaśnienie mechanizmów nim rządzące,j przyczyny i konsekwencje takiego, a nie innego podziału ról społecznych podczas obróbki surowca. Po pierwsze, musimy się tutaj odnieść do jednego z dwóch wspomnianych przeze mnie wymiarów tkactwa, które miały fundamentalny wpływa na to, jak role społeczne się tworzyły i jak je realizowano w wymiarze praktycznym i symbolicznym.

W przypadku Łowicza przetwórstwo to odbywało się na skalę domowa, ewentualnie ograniczoną do małej społeczności, jaką była wieś. Realizował się więc schemat przędzenia i tkania jako domeny czysto kobiecej, w której to ona sprawowała pieczę nad przetwarzaniem rośliny najpierw w czyste włókno, a następnie w tkaninę. Mężczyzna zajmował się zbiorem, zwożeniem, moczeniem i młóceniem, a więc czynnościami związanymi z innymi praktykami gospodarczymi, do których potrzebna była siła i zaplecze w postaci wozu i konia. Można uważać, że taki podział znamionuje coś zgoła innego niż sugerowałam wcześniej. To mianowicie, że to mężczyzna związany był z naturą - musiał w końcu posiadać wiedzę, kiedy len zbierać, jak moczyć, kiedy jest już gotowy, jak młócić i kiedy przestać. Kobieta natomiast wykorzystywała wiedzę techniczną - obsługi kołowrotka, motaka, wijadeł czy wreszcie krosna, którą można przyporządkować sferze kultury.

Tak więc, z takiego punktu widzenia opozycja natura - kultura nie realizuje się tutaj w schematyczny sposób. Jeżeli chodzi o dychotomię domowe - publiczne, to jeżeli ujać sprawę przede wszystkim przez pryzmat przestrzeni fizycznej, w której kobiety i mężczyźni realizowali swoje działania, to faktycznie, miała ona miejsce. Tym niemniej, taka interpretacja wydaje mi się nieco prymitywna. Oczywiście, opozycja domowe - publiczne jest związana z jakością przestrzeni, ale przecież nie wyłącznie. Obejmuje również sferę symboliczna, która związana jest ze sposobem realizacji tych działań, lokalnych, kulturowych konotacji i znaczeń. Nie jest więc powiedziane, że akurat $\mathrm{w}$ tym przypadku owe binarne opozycje mają wartość analityczną. Być może to jest właśnie ten przypadek, w którym inne kategorie okazują się bardziej przydatne.

\section{Podsumowanie}

Efektem wielu współczesnych badań genderowych jest dekonstrukcja przedstawionych przeze mnie dychotomii. Szczególnie badaczki z tego nurtu zdają się wątpić $\mathrm{w}$ ich analityczną użyteczność i kulturową uniwersalnośćt ${ }^{40}$. Bardzo dobrym przykładem jest artykuł, na którym oparłam się w swoim tekście ${ }^{41}$ - on także próbuje poddać krytyce owe założenia i zastosować zupełnie odrębny, niezwiązany żadnymi pierwotnymi presupozycjami punkt widzenia. Autorki jednak przyznaja, że jest to bardzo trudne i im samym udaje się to wyłącznie po części. Dla mnie, uczącego się antropologa, ten problem jest całkowicie zrozumiały. Relatywizm kulturowy, o którym już wspomniałam, postulaty zawieszenia swojego punktu widzenia, wystrzeganie się oceniania i wynikający z tego zupełny obiektywizm (postawa emic) jest czymś niesłychanie trudnym do osiagnięcia.

Tym trudniejsze wydaje się wyjście z ram postrzegania pewnych zjawisk we własnej kulturze, gdzie nie mamy szansy na jakikolwiek samowytwarzający się dystans, tak jak podczas badań antropologicznych prowadzonych nad innymi kulturami. Porzucenie silnie ukonstytuowanego punktu widzenia, który dodatkowo nie jest wyłącznie naszym własnym,

39 S. J. Yanagisako, J.F. Collier, dz. cyt., s. 22.
40 S. J. Yanagisako, J.F. Collier, dz cyt., s. 53.

41 Tamże. 
a raczej czymś w rodzaju faktu społecznego w durkheimowskim ujęciu (folk models) ${ }^{42}$, przysparza dwukrotnie więcej problemów. Co jednak można osiągnąć dzięki takiemu wyjściu z ram? Być może nową jakość analizy, świeżość spojzzenia, nowe kierunki dla współczesnych nauk społecznych.

Mam świadomość, że powyższa próba analizy jest pod wieloma względami niedoskonała, lecz z pewnością nakreśliła ramy pojmowania tego zjawiska w szerszym niż lokalne, etnograficzne. Spróbowała także wyjaśnić zaobserwowane przeze mnie mechanizmy. Analiza sfery symbolicznej i rzemieślniczej odsłoniła pewne podobieństwa, powtarzalne schematy i, uświadomiła czytelnikowi, jak złożonym i fascynującym zjawiskiem jest, bądź co bądź, przeplatanie jednej nitki przez druga.

\section{Bibliografia}

[1] Buchowski M., Burszta W., O założeniach interpretaçi antropologicznej, Warszawa 1992.

[2] Hryciuk R., Kościańska A., Wstẹp, [w:] R. Hryciuk, A. Kościanska (red.), Gender. Perspektywwa antropologiczna. Organizacja spoteczna, T. 1, Warszawa 2007.

[3] Miller N. K., Arachnologie: kobieta, tekst i krytyka, [w:] A. Burzyńska, M. P. Markowski (red.), Teorie literatury XX wieku. Antologia, Kraków 2006.

[4] Szacki J., Historia myśli socjologicznej, Warszawa 2012.

[5] Szczuka K., Przadki, tkaczki i pajaki, [w:] Krytyka feministyczna: siostra teorii i historii literatury, Warszawa 2000.

[6] Toussaint-Samat M., Historia stroju, Warszawa 1998.

[7] Wróblewski T., Jeszzze i krosnach i tkactwie, Warszawa 1958.

[8] Yanagisako S. J., Collier J. F., O ujednolicona analizę ptci kulturowej i pokrewieństwa, [w:] R. Hryciuk, A. Kościańska (red.), Gender. Perspektywo antropologiczna, T.1. Organizacja spoteczna Warszawa 2007.

[9] Żmijewska M., Ginace rzemiosta = Disappearing handicraft, Czeremcha 2011.

\section{NetOgRAFIA}

[10] Goddeses Who Weave and Spin, http://www.crystalinks.com/weaving_goddess.html, 15.12.2014.

[11] Kowalczuk W., Propozycja dla koneserów sztuki ludowej, http://www.wrotapodlasia.pl/pl/kultura/sztuka_ludowal, 15.12.2013.

[12] Mencel I., Natura w śtwiecie kultury, www.racionalista.pl, 15.12.2013.

[13] On the mythology of weenving, http://tres-hermanas-weaver.blogspot.com/2009/09/on-mythology-of-weaving.html, 15.12.2013.

[14] http://www.allfiberarts.com/library/aa01/aa021901.htm, 15.12.2013.

[15] http://en.wikipedia.org/wiki/Weaving_(mythology), 15.12.2013.

[16] http://www.grimmstories.com/en/grimm_fairy-tales/the_spindle_the_shuttle_and_the_needle, 15.12.2013.

[17] http://www.penn.museum/sites/Canaan/Weaving.html, 15.12.2013.

[18] http://www.reshafim.org.il/ad/egypt/timelines/topics/llax.htm, 15.12.2013.

42 J. Szacki, Historia myśli socjologicznej, Warszawa 2012, s. 372-405. 